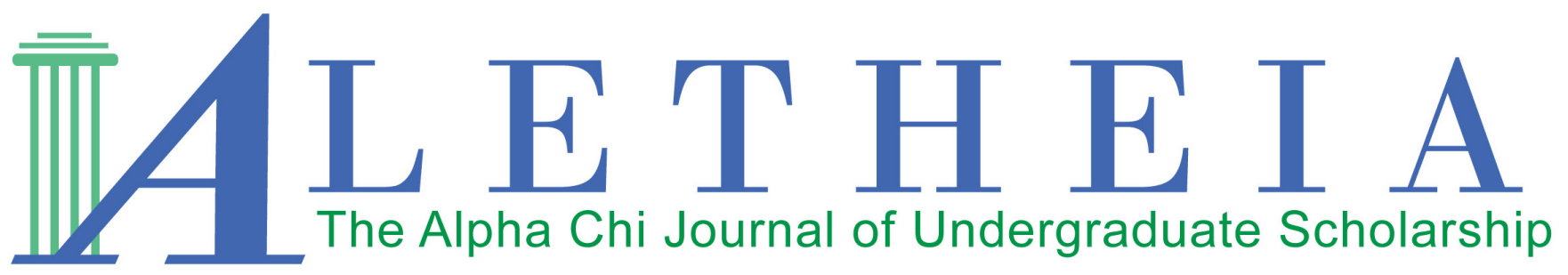

Volume 6 | Issue 2 | 2021

\title{
China's Media Rhetoric: The Re-Framing of China's Neocolonialism
}

\author{
Madison E. Taylor \\ Christopher Newport University \\ Virginia Zeta Chapter
}

Vol. 6(2), 2021

Title: China's Media Rhetoric: The Re-Framing of China's Neocolonialism

DOI: $10.21081 / \mathrm{ax} 0291$

ISSN: 2381-800X

Keywords: China, Geopolitical Power, Neocolonialism, Media Censorship, Framing

This work is licensed under a Creative Commons Attribution 4.0 International License.

Author contact information is available from tlindblom@alphachihonor.org or kvosevich@alphachihonor.org

\section{Aletheia-The Alpha Chi Journal of Undergraduate Scholarship}

- This publication is an online, peer-reviewed, interdisciplinary undergraduate journal, whose mission is to promote high quality research and scholarship among undergraduates by showcasing exemplary work.

- Submissions can be in any basic or applied field of study, including the physical and life sciences, the social sciences, the humanities, education, engineering, and the arts.

- Publication in Aletheia will recognize students who excel academically and foster mentor/mentee relationships between faculty and students.

- In keeping with the strong tradition of student involvement in all levels of Alpha Chi, the journal will also provide a forum for students to become actively involved in the writing, peer review, and publication process.

- More information can be found at www.alphachihonor.org/aletheia. Questions to the editors may be directed to tlindblom@alphachihonor.org or kvosevich@alphachihonor.org.

Alpha Chi National College Honor Society invites to membership juniors, seniors, and graduate students from all disciplines in the top ten percent of their classes. Active on nearly 300 campuses nationwide, chapters induct approximately 10,000 students annually. Since the Society's founding in 1922, Alpha Chi members have dedicated themselves to "making scholarship effective for good." Alpha Chi is a member in good standing of the Association of College Honor Societies, the only national accrediting body for collegiate honor societies. A college seeking a chapter must grant baccalaureate degrees, be regionally accredited, and be a not for profit institution. 


\title{
China's Media Rhetoric: The Re-Framing of China's Neocolonialism
}

\author{
Madison E. Taylor \\ Christopher Newport University \\ Virginia Zeta Chapter
}

\begin{abstract}
This essay explores how China's political media utilizes skewed framing and "win-win" rhetoric to conceal its intentions with foreign partnerships. China's intervention in Brazil, Africa, and Taiwan demonstrates the negative effects resulting from China's engagement. Moreover, China's domestic policies regarding censorship and propaganda serve to shape the narrative from within the country and rally support for the Chinese Communist Party (CCP) and leader Xi Jinping. China's modern media discourse surrounding foreign intervention highlights the importance of global engagement and promotes its major global trade route infrastructure project, the Belt and Road Initiative (BRI). China provides countries with excessive loans to cover the costs of industrialization, raising the concern over whether China's economic participation illustrates Debt Trap Diplomacy in order to gain economic and political control in various regions of the world. With the shift toward global involvement, China's expectations for domestic media usage changed to convey the perception of free press and open media engagement. However, censorship, specifically regarding political dissent, still comprises China's domestic media control.
\end{abstract}

Keywords: China, Geopolitical Power, Neocolonialism, Media Censorship, Framing 
While the world watches, China redefines the narrative on its foreign affairs and domestic media policies through the strategic use of rhetoric - the intentional composition of language for the purpose of effective persuasion. Through regulating media and establishing political footholds to monopolize resources and economies worldwide, China engages in neocolonialism, which sets a dangerous tone for its geopolitical power. Modern colonialism, or neocolonialism, encompasses the use of economic and political pressure to extract resources and administer control over less developed countries, according to Encyclopcedia Britannica contributor Sandra Halperin (2020). One major driving force for China's indirect control over other countries, its rhetorical strategy, functions at both a domestic and an international level to shape the narrative of China's influence. China's leadership establishes rhetorical initiatives that encourage its global intervention, but ambiguity and political ambition surround many of these initiatives. Political survival binds leaders to the will of their constituents; for this reason, China's media strategy seeks to paint the actions of the Chinese Communist Party (CCP) in the best possible light. Through examining China's rhetorical strategy in cohort with case studies comprised of key economic partner countries, this essay posits that China shields the reality of its neocolonialism through media rhetoric, both domestically and internationally.

\section{Political Context}

Sweeping changes to China's foreign policy occur as new leaders veer into more open-market approaches to international relations. Although China's past few decades of foreign policy pushed globalization, the 2013 election of Xi Jinping brought a rapid escalation into the global economy as he implemented and strengthened various policies to encourage domestic businesses to engage in other economies. One such policy, dubbed "Go Global," first arose in China in the early 2000s. As described by Sino-African researcher Dr. Beyongo Mukete Dynamic (2019), the policy urges "Chinese companies to invest abroad, acquire strategic resources, and gain a foothold in overseas markets" (p. 190). The Go Global policy inspired the creation of President Xi Jinping's campaign slogan: The "China Dream." According to CNN writer Ben Westcott (2018), the sweeping motivational campaign sought to rejuvenate the Chinese economy on a global scale. According to BBC News (2013), the concept lacks clear implications. The words evoke a glittering generality conveyed by the media to circulate the idea that Xi Jinping's leadership could bring about individual goal achievement in many different realms (BBC News, 2013). Xi Jinping steers the public toward the term's inclusivity rather than ambiguity. Leaving the term broad serves another purpose; it paints a hopeful vision for the future of China and insinuates that the country needs the CCP to achieve that dream (Westcott, 2018).

The Go Global policy originated from the early1990s strategy "socialism with Chinese characteristics," which aspired to resolve the longstanding issue of authoritarian control clashing with free market success in China (Westcott, 2018). Xi Jinping's modern take on the policy, dubbed "Xi Jinping Thought," emphasizes state-sponsored capitalism at a global level as the stable solution to maintaining autocratic leadership (Westcott, 2018). Researchers for Harvard Business Review Sebastian Horn, Carmen M. Reinhart, and Christoph Trebesch (2020) point out that China's strategy to lend at market terms, replicating the constraints of private business, serves to exploit capitalistic principles for economic dominance. Branding the president's name on the policy associates China's economic success with President Xi's heightening power. New York Times correspondent Chris Buckley (2018) highlights how China recently abolished the presidential term limit just as President Xi received a promotion to the Core of the CCP.

The CCP experiences contradicting pressures to emanate domestic self-sufficiency while maximizing global trade connections - enter the Chinese policy of Dual-Circulation. As writer for The Economist Fengyang (2020) asserts, Dual-Circulation revises China's sole goal of attaining external economic leverage to refocus on investment in domestic production. Constructing fully internal supply chains allows the CCP to gain full control over the country's production while additionally removing foreign players from the Chinese economy (Fengyang, 2020). For now, China contends with the unfavorable global opinion of the CCP's economic reach and the country's rhetorical strategies attempt to optimistically convey the power "of the Communist Party to growing numbers of avid consumers, internet users and world travelers" (Buckley, 2020). Domestically, these rhetorical approaches for 
globalization jumpstarted patriotically driven public support for President Xi's economic foreign policy - the One Belt One Road Initiative (BRI) (BBC News, 2013). China's encouraging rhetoric of increasing global interconnectedness shielded a bigger problem: in order to reestablish stability in an economy growing too quickly, China relied heavily on external relationships. By 2013, China became "the largest trade and investment partner of Africa" as it continued to seek resources abroad, and the same applies for many of the other countries where China invests (Dynamic, 2019, p. 188). Writer for The Interpreter Anthony Kleven (2019) describes it as no coincidence that China emerges as the dominant trade partner of the regions where it invests. China's global strategy applies pressure economically and politically to extract resources and to extort them.

\section{China's Neocolonialism}

The BRI aims to create an interconnected series of trade routes around the globe. China's government officials promote the project as a "win-win" strategy that stimulates the economies of participating countries while also benefiting China's economy and accessibility to global resources. The rhetoric behind a win-win strategy shields the public from any self-interested goals China may have for a foreign partnership; the mutual success of the countries protects China from being viewed as imperialistic. While the national discourse of the Chinese government perpetuates the mutuality of the relationships, upon closer inspection, the countries involved often suffer severe environmental, economic, and political consequences. Given the growing geopolitical power of China, countries harmed by China's involvement do not have the means to address their concerns on a global scale. Analyzing instances of China's foreign influence provides a great deal of context as to the impact of its rhetorical initiatives. Taking Brazil, Africa, and Taiwan as case studies where China's involvement challenges their rhetorical narratives, this analysis succinctly covers the reality of China's foreign intervention.

\section{Brazil}

China relies heavily on food imports from Brazil; reporters for The Atlantic Melissa Chan and Heriberto Araújo (2020) note that China recently became Brazil's biggest customer for soy and beef. Brazil currently competes against the United States for global soy production, but the 2016 U.S. election of President Trump shifted trade relations between the countries. Hong Kong-based correspondent Anthony Li (2017) cites Xi Jinping's election, which pushed globalization and increased market participation, as a threat to U.S. global power. President Trump's 2016 presidential campaign rhetoric highlighted this concern and sought to win votes through appearing tough on China: "Trump took advantage of existing Sino-American intentions to castigate China for manipulating its currency, pursuing an imbalance of trade with the US, stealing manufacturing jobs from the US, fabricating the hoax of climate change, etc." (Li, 2017, p. 70). U.S. policies such as "Pivot to Asia" and the Trans-Pacific Partnership (TPP) focused on maximizing American reach in Asia while simultaneously excluding China from trade and partnerships to every extent possible (Li, 2017). As a result, China turned to Brazil for production and exportation of the food necessary to feed its massive population. Brazil's production increased exorbitantly to meet China's demand. Unfortunately, the current methods for soy and beef production in Brazil impede environmental initiatives in the region and lead to deforestation of the Amazon rainforest.

Environmental protection groups advocate for sustainable international agreements, including the Soy Moratorium. According to the global environmental activism group Greenpeace (n.d.), which drafted the pact, the Soy Moratorium stood as an international agreement to abstain from purchasing soy harvested on newly deforested Amazon rainforest lands. Unfortunately, China's heavy reliance on Brazilian resources largely reversed the initial success of the Soy Moratorium (Chan \& Araújo, 2020). Despite the correlation between meeting China's demand for soy and beef and irreconcilable harm to the rainforest, China has denied having any connection to the environmental issues plaguing the Amazon (Chan \& Araújo, 2020). When asked about China's role in the destruction of the Amazon, its spokesman Geng Shuang dismissed the connection, stating: "the correlation is new to me" (as cited in Chan \& Araújo, 2020). China's infrastructure projects in the rainforest cause further damage to the surrounding environment.

China views Brazil as a major leg of the BRI and seeks to stimulate trade by investing in infrastructure 
improvements (Chan \& Araújo, 2020). Renovated infrastructure throughout the Amazon rainforest region would significantly decrease costs and improve delivery times for Brazilian exports, which, in turn, benefits China's trade relationship. Additionally, Chinese-owned companies submit bids on the contracts to manage these infrastructure projects. Therefore, the invested money often goes directly into the hands of Chinese businessmen while the long-term cost improvements benefit China as well. The façade of mutuality in the rhetoric between political leaders serves to manipulate not only the countries' citizens but also global awareness of the parameters of these international relations. The political discourse between leaders hinges on the economic relationship between their countries; with China dipping its hand into markets worldwide, many global leaders deem China a respected economic alliance.

Economist Steve Levitt (2020) highlights that Brazilian President Jair Bolsanaro expresses continued support for China's investment in the country as he attempts to uphold his campaign promises to rectify the $12 \%$ unemployment rate plaguing the Brazilian economy by scaling back the environmental regulations of the Amazon. Similar to President Trump, Bolsanaro's campaign platform sought to address national concerns about China's growing reach in the Brazilian economy. Latin American consultant Richard Lapper (2019) discusses Bolsanaro's early attitudes toward China as gathered from congressional assemblies. Bolsanaro vehemently attacked China's dealings in Brazil, warning that China sought to capitalize on Brazilian resources, such as the steel additive niobium, through buying up land. China willingly invests over market value for products and corporations that provide long term payoff in one way or another (Lapper, 2017). However, once Bolsanaro was elected, he found business ties with China too deep to upend. In an article by the South China Morning Post, Xi speaks of the growing relationship with Brazil, citing his hopes to "strengthen multilateralism and build an open world economy" ("China Part of Brazil's Future," 2019). The Chinese-based news source discusses Bolsanaro's misguided anti-China approach to campaigning, which no longer stands now that Bolsanaro holds the presidency; Bolsanaro "had threatened to torpedo the relationship during last year's election campaign when he accused China of 'buying Brazil,' and his pro-business government has been trying to repair the damage ever since" ("China Part of
Brazil's Future," 2019). Overlooking the relationship is impossible for the struggling economy of Brazil, as shown by Bolsanano's drastic switch to favor Chinese business in Brazil.

Due to the political tension between the U.S. and China, Brazil continues to take on a larger role in providing for China's interests. China's engagement in Brazil has resounding consequences for foreign interference in three major areas - environmental, economic, and political. The rhetorical strategies of conveying "win-win" mutual benefit through economic stimulation corner Brazil into a bilateral trade agreement. Meanwhile, China drains Brazilian resources and causes irreparable harm to the environment (Chan \& Araújo, 2020). Many of China's foreign interventions rely on some form of economic entrapment.

\section{Africa}

China's economic investment in certain regions of Africa, namely Zambia and Ethiopia, brought an era of economic prosperity to the countries while simultaneously causing other severe economic issues (Dynamic, 2019). Both Zambia and Ethiopia amassed exorbitant debt to China to such an extreme that economists fear for their inevitable collapses. Ethiopia saw a period of rapid growth fueled by China's economic initiatives. China divided the country into economic zones and "outsourced major Chinese manufacturers to the region which provided jobs and stability for Ethiopia while also acquiring cheap labor for Chinese companies" (Dynamic, 2019, p. 191). As the host of the African Union, Ethiopia warranted a strong geopolitical foothold in Africa for China. These political relationships span decades; in the 1970s, China's economic relationship with African countries also functioned to secure African support for China joining the United Nations (Dynamic, 2019). Beyond forging political ties, for China, Zambia's lucrative copper mines served as an underutilized resource to implement in its African-based manufacturing facilities (Dynamic, 2019). Scholars speculate that China employs economic entrapment through Debt Trap Diplomacy to gain economic influence across the globe (Dynamic, 2019).

Debt Trap Diplomacy occurs when a creditor country provides extortionate loans to an underdeveloped country, causing economic entrapment. Mark Green (2019), administrator of the U.S. Agency for International 
Development, warns world leaders of "China's efforts to use its Belt and Road Initiative (BRI) to broaden its geopolitical and economic clout" by way of "saddling developing countries with unsustainable debt while increasing their dependency on China." Green (2019) references the initially successful U.S. global debt forgiveness program, which sought to revive collapsing economies, but China's BRI loans now undermine the success of the program. China gains economic and political footholds in the burgeoning economic growth of the countries while simultaneously concealing the terms of the loans, and 'developing countries' strategic assets, such as their resources, mineral deposits, port access rights, and the like, are now targeted by creditors as collateral in many of these predatory deals" (Green, 2019). Some pro-China critics argue that China provides aid to countries bound for collapse, but this rhetoric does not justify the predatory nature of the loans (Dynamic, 2019; Green, 2019). Countries rely on China because they lack alternate options for aid, but their inevitable failure to repay the multibillion-dollar infrastructurebased loans "can result in a loss of strategic assets, major hurdles to economic development, and a loss of sovereignty" (Green, 2019). In Africa, President $\mathrm{Xi}$ continually leverages the Chinese investments for economic dominance and resource exports, making China the world's largest net importer of many of African's fossil fuel resources (Dynamic, 2019). To professor of Chinese politics Julie Strauss (2012), the statistics that highlight China's international infrastructure support as being mutually beneficial only portray a part of the story. The trade partnerships remain imbalanced and unsustainable; "Not surprisingly, many Africans and Latin Americans are troubled by concerns over sectorial asymmetry in trade relations, as well as less tangible but nevertheless powerful perceptions of unevenness in influence, leverage and sheer scale" (Strauss, 2012). The scrutiny of China's economic interventions poses a threat to the international acceptance of China's infrastructure projects. Dynamic (2019) contends that these actions demonstrate how China's neocolonialism uses money to "buy influence" (p. 189). Another rhetorical device that contributes to obscuring China's neocolonialism, "the narrative of 'common interest' or 'convergence of interests,", plays out through China's political overreach in Africa (Dynamic, 2019, p. 189).

China's self-proclaimed role in Africa encourages the narrative that it industrializes underdeveloped countries, setting a precedent for mutual economic and diplomatic cooperation while advancing the African countries' independence. At the Beijing summit of the Forum on China-Africa Cooperation (FOCAC), President Xi Jinping highlighted "the common interests and shared vision of China and Africa and their mutual responsibility to champion peace and development through brotherly cooperation, and win-win solutions" (Dynamic, 2019, p. 186). The political rhetoric of the countries involved reflects these same ideas, as African political leaders express nothing but gratitude for China's investments. In 2015, Zambian President Lungho conveyed appreciation to China for its aid in stabilizing the region and in facilitating Zambian independence. This political rhetoric does not align with the views of the Zambian people, who have protested China's exploitation of the region for cheap labor and leveraging of financial investments for political influence (Dynamic, 2019). Deputy editor of Guardian Cities Nick Van Mead (2018) breaks down how China's influence in Africa demonstrates carefully calculated colonization of the region that seeks to remain on the positive side of the media. Van Mead (2018) addresses the harsh reality that African residents face when massive Chinese infrastructure projects come to their regions: the displacement of residents, upheaval of small businesses, and destruction of natural resources.

Many of Africa's underdeveloped countries exist as a wealth of untapped resources and unregulated space; China's framing strategy purports the mutual benefits from the Sino-African common interests, but China's aid inflicts a great deal of harm on the economic stability and political sovereignty of the countries involved. As seen with China's involvement in Africa, identification and enforcement of Debt Trap Diplomacy proves extremely difficult, especially given China's ability to reshape the narrative around the salvation of struggling countries.

\section{Taiwan}

The case study of Taiwan provides further insight into how China's global media policies aid in its neocolonialist actions. Taiwan, a small country off the coast of mainland China, experiences pressure from China to reunite as a province of the mainland. BBC News (2020) documents the recent developments in the contentious cross-strait relations; although Taiwan 
refuses China's offer of reunification and seeks to remain a sovereign state, the country loosened its anti-China policies throughout the past few decades. These changes in regulations moved parallel with the increasing independence of Taiwan, but open competition brings China back to the forefront of the Taiwanese economy. More specifically, Taiwan's development of free press grants equal access to external players; therefore, China exercises influence through purchasing media outlets in a process known as horizontal integration.

Investopedia writer Will Kenton (2020) defines horizontal integration as "the acquisition of a business operating at the same level of the value chain in the same industry." Integrating in this manner increases the competitive edge of the business by providing more prospects for revenue and growing its market share. However, competition between businesses of the same type drives prices down; when a company acquires the majority share of the market, it functions as a monopoly (Kenton, 2020). Author Chien-Jung Hsu (2014) attributes the resurgence of China's media control in Taiwan to its emergent open markets, which grant access to China's horizontal integration in Taiwanese media. The People's Republic of China (PRC) asserts three approaches to reshaping Taiwanese media:

First, the PRC encourages tycoons with pro-China views to purchase Taiwan's media outlets. Second, it pressures media proprietors who have invested or intend to invest in China. Third, it uses embedded advertising/ advertorials in Taiwan's media to influence media and public opinion. (Hsu, 2014, p. 517)

The Want Want China Times Group employs many of the aforementioned strategies. Taiwanese business tycoon Tsai Eng-meng began to invest in China during the international boycotts of China that transpired after the Tiananmen Square massacre. Not only did Tsai Eng-meng deny the massacre occurred, he also claimed the media villainized China in its coverage of the event (Hsu, 2014). Competitors speculate that China financed Tsai Eng-meng's media acquisitions in Taiwan; money trails show funds were transferred by Chinese government agencies, which correlated with the amounts spent on Tsai Eng-meng's mergers (Hsu, 2014). While providing direction for his newly acquired media conglomerate, Tsai Eng-meng ordered the preexisting senior managers of the company to focus on improving cross-strait relations by ceasing all coverage of Taiwanese independence (Hsu, 2014).
China exhorts its global economic dominance to shape its relationship with Taiwan in the eyes of its economic partners. China's media strategy compounds that influence: "Throughout 2018, China stepped up pressure on international companies forcing them to list Taiwan as a part of China on their websites and threatening to block them for doing business in China if they failed to comply" (BBC News, 2020). The U.S. maintains "strategy ambiguity" as its stance towards Taiwanese independence, leaving the world to wonder whether the U.S. would engage militarily if China attempted to reunify Taiwan by force. The Trump administration verbalizes anti-China rhetoric publicly and within Congress, but the 2020 election of candidate Joseph Biden Jr. poses a new era for Sino-American foreign relations. As Trump's rhetoric often sought to undermine China's global power by supporting Taiwan, Biden faces a complex and tense situation. China correspondents for the New York Times Javier Hernández and Amy Chang Chien (2020) predict Biden will uphold Trump's approach, which recognizes Taiwanese independence, as bowing to China's wishes appears weak and implies the U.S. would not intervene if military action ensued. The political discourse of the leaders holds dire consequences and both China and the U.S. appear to calculate the risks and benefits of their choices regarding cross-strait relations.

China's strategy in Taiwan focuses on horizontal integration through media to perpetuate pro-China narratives. China's economic and political interests in Taiwan relate to its desire to reunify and claim Taiwanese trade and production as its own. Through this method, China offsets the need for force and attempts to manipulate the citizens of Taiwan into losing faith in Taiwanese sovereignty. China increasingly wrestles with autonomy and control as it navigates the power of its national rhetoric.

\section{China's Media Rhetoric}

China's emergence into the global market prompts unavoidable media exposure. Rather than shying away from the public eye or utilizing authoritarian means of suppression, China seeks to steer its coverage in the media. Professor John Fitzgerald (2019) details China's relationship with the media in terms of moderating public opinion. The CCP utilizes propaganda to shape the public narrative. According to Fitzgerald (2019), the 
CCP spends around $\$ 10$ billion per year to influence and control the representation of China in media sources around the world:

The aim is to foster a positive image of China under $\mathrm{CCP}$ rule and curate local conversations about issues of particular concern in order to shape other governments' policies and programs in ways that favor China's commercial interests and long-term strategic goals. (p. 4)

Reuters foreign policy reporters Engen Tham and Matthew Miller (2016) point out that China pursues consultant input to direct its media policies for restoring communication with the West. Tham and Miller (2016) discuss the Chinese government's motivations for interviewing public relations firms and find that the decision "comes amid intensifying scrutiny of Chinese companies abroad, a crackdown on dissent at home and rising tensions in the South China Sea." Beyond the BRI, China uses rhetorical influence to shift its relationships with other countries to its own benefit.

Of China's modern media policies, censorship policies such as the Great Firewall work to establish domestic order. Ralph Schroeder (2018), an electronic science professor at Oxford University, points out how "China's media system is commonly seen in terms of censorship and authoritarian control," but at the same time "the party state is pushing media to become a tool for gauging public opinion in order to maintain social order" (p. 46). Along with the changing media landscape of the digital age, internet literacy emerged as a characteristic of developed countries. China's authoritarian government allots them the power to establish the parameters for domestic media usage but eradicating internet access risks leaving China behind in the race for geopolitical power. Therefore, China looks for ways to cater domestic media to its needs while maintaining a tight grasp of national sentiments. Writer for The Guardian Elizabeth Economy (2018) discusses the changes implemented since President Xi Jinping's election:

The government has invested in technological upgrades to monitor and censor content. It has passed new laws on acceptable content, and aggressively punished those who defy the new restrictions. Under $\mathrm{Xi}$, foreign content providers have found their access to China shrinking. They are being pushed out by both Xi's ideological war and his desire that Chinese companies dominate the country's rapidly growing online economy.
One technological development, the Golden Shield, grants the government full access to all data sent or received within the country, including IP information that identifies the user. China's knowledge of internet technology has subsequently improved throughout the years; in the mid-2000s, citizens skirted the Great Firewall by downloading VPNs, but China recently blocked the technology (Economy, 2018). While the government does not tolerate political dissent in its media, citizens commonly engage in political discourse. China uses this to its advantage by planting pro-China internet commentators who receive compensation for guiding "online discussions in politically acceptable directions and report comments that did not follow Chinese law" (Economy, 2018). China's past reliance on propaganda to shape domestic public opinion has changed drastically since opening to globalization, and its technological prowess has increased accordingly. However, with little to no global regulations on media censorship and framing, global media theorists raise the question of whether China should be held accountable for fair media portrayal. Moreover, China's ambitious and authoritarian media agenda-setting presents a major concern for fair access to information, but many other countries exhibit media framing through their own rhetoric as well - global regulations would extend beyond China.

\section{Counterarguments}

Although evidence documents China's use of calculated media strategies to shape its global image, the same could be argued for all geopolitical superpowers. Building and maintaining international relationships warrant the use of deliberate rhetoric for any foreign action or policy. Critics argue that when Western countries paint China as the sole perpetrator of neocolonialism, the rhetoric functions to reshape its own global influence. Oxford Political Review contributor Rohan Shah (2020) reasons that in European political rhetoric, fixating on the harm imposed by China's intervention simultaneously obscures "the damaging economic and cultural repercussions of the legacy of European colonialism." This strategy serves to distance countries from the notion of neocolonialism, concealing how "former European colonial powers, including Britain, also continue to facilitate their own economic and political interests via intervention in former colonies" (Shah, 2020). While to some extent all countries 
shape media strategies to characterize themselves as positive players in the global economy, China's style of authoritarianism enables stronger control over the narrative. In the United States, media competition seeks to encourage transparency and free speech. European countries and the United States participate in privately driven economic partnerships rather than centrally planned engagements; therefore, the national interests do not fully direct the will of the people and of private business (Horn et al., 2020). Although China attempts to convey that its newfound openness extends to domestic media usage, it remains vastly different from Western countries regarding censorship practices. Rather than serving to inform the public, China's media protects the interests of the CCP first and foremost by reporting stories that favor the current leadership and burying those that do not (Blumenthal, 2020). In a comparative study between European imperialism and China's neocolonialism, Assistant Professor Dr. Osman AntwiBoateng (2017) concludes that China's exploitative bilateral trade policies in Africa amplify its global dominance; China's extortion of African resources through trade depicts "mutually beneficially economic cooperation in a pragmatic attempt to navigate a norm driven international system and institutionalized world community" (p. 192). China's attempt to rebuild its image around the ideals of Western civilization amplifies the concern that its rhetoric, as well as its direct engagement, seek to create relational culpability.

\section{Conclusion and Implications}

The analysis of China's media rhetoric illuminates how "different strands of China's official rhetoric are both extraordinarily consistent over time and logically inconsistent at any given point" as China implements new directions with its rhetorical strategies that fail to accurately reflect its impact on foreign entities (Strauss, 2012, p. 138). Allowing China to set the agenda for its representation in the media, as the situation appears currently, inhibits transparency domestically and abroad. The new age of China's global media strategy may legitimately mean that the world must contend with its geopolitical power and reach or impose sanctions to regulate China's economic strategy and/or media framing. China's media strategy warrants serious concern, especially given the severity of the implications of the country's growing global economic influence.
As China's global strategy continues to drive forward unrestricted by other major geopolitical players, its influence reaches a turning point where it essentially acts as a puppet-master in other economies. Horn et al. (2020) describe the magnitude of the world's increasing debt to China: "Over the past two decades, China has become a major global lender, with outstanding claims now exceeding more than 5\% of global GDP." As a result of its strategic rhetorical approach, "debtor countries and international institutions alike have an incomplete picture on how much countries around the world owe to China and under which conditions," creating a problem referred to as "hidden debt" (Horn et al., 2020). Many critiques of China's loan strategy express concern for violence, but China's approach intentionally negates conflict. Attaining foreign debt provides China access to the inner workings of a country's economy; therefore, China would be relinquishing its influence if it decided to claim repayment. China's loan strategy poses significant risk to international sovereignty and proves more prevalent than violence as China's economic engagement spreads across South America, Africa, and Asia. To reduce the weight of this problem, economists and politicians alike suggest constructing universal expectations for international loan transparency, as projections show that $50 \%$ of China's loans to undeveloped countries went unreported to international monetary agencies (Horn et al., 2020). Instituting regulations to increase China's loan disclosure provides a start to establishing fair and economically sustainable global market access.

Moreover, if the world follows its current path of noninterference, global order potentially risks upheaval. With China's authoritarian government at the helm, the world may need to contend with the possibility of losing more and more free speech and open access to information. China already endeavors to change regulations for international media regulation; China proposed new regulations to the United Nations regarding each country's ability to control its internet (Blumenthal, 2020). If passed, preventing China's domestic media censorship and its use of propaganda would become much more challenging. Blumenthal (2020) suggests multiple strategies for enacting swift interference against China's media regulations. As China's media gains traction in the West due to its horizontal integration and publication in the English language, the U.S. allows China to shape the narrative. By establishing news 
sources in Chinese languages, the U.S. would begin to counter China's propaganda and deliver more options for reliable sources to the people of China (Blumenthal, 2020). Taiwan and other countries impacted by China's influence benefit from the integration of differing perspectives on global power. Blumenthal (2020) also argues that entertainment industry leaders in the West who cater media content in order to gain entry to China's highly filtered media landscape perpetuate the acceptance of China's censorship practices.

Given the current state of China's media policies, it would be unwise to underestimate China's growing geopolitical power. Although the West remains skeptical of China's foreign economic engagements and internal use of propaganda, many countries fail to view rhetorical strategy as a prominent concern worthy of intervention. The cases of Brazil, Africa, and Taiwan, in addition to China's domestic strategy, depict the magnitude of China's influence and its ability to regulate its control through media rhetoric. Without preventative action, China attains the prospect of emerging as the top geopolitical superpower. Other major geopolitical powers, such as the U.S. with its policy of strategic ambiguity, indicate that they would counter any hostile takeover attempt by China with equal opposing force, but China's methods depict a more subtle approach to increasing its global footholds. The reality of China's long-predicted pursuit of global dominance occurred in an unexpected form; it stemmed not from wars, but from words.

\section{References}

Antwi-Boateng, O. (2017). New world order neocolonialism: A contextual comparison of contemporary China and European colonization in Africa. Africology: The Journal of Pan African Studies, 10(2), 177-195.

BBC News. (2013, June 5). What does Xi Jinping's China Dream mean? BBC News. https://www.bbc.com/ news/world-asia-china-22726375.

BBC News. (2020, September 28). What's behind the China-Taiwan divide? BBC News. https://www.bbc. com/news/world-asia-34729538.

Blumenthal, D. (2020, July 10). China's censorship, propaganda \& disinformation. American Enterprise Institute.https://www.aei.org/articles/chinascensorship-propaganda-disinformation/.
Buckley, C. (2018, February 26). Xi Jinping thought explained: A new ideology for a new era. The New York Times. https://www.nytimes.com/2018/02/26/ world/asia/xi-jinping-thought-explained-a-newideology-for-a-new-era.html.

Chan, M., \& Araújo, H. (2020, February 15). China wants food. Brazil pays the price. The Atlantic. https://www. theatlantic.com/international/archive/2020/02/chinabrazil-amazon-environment-pork/606601/.

China part of Brazil's future, Jair Bolsonaro says as he and $\mathrm{Xi}$ Jinping sign transport and investment agreements. (2019, November 13). South China Morning Post. https://www.scmp.com/news/world/ americas/article/3037631/china-part-brazils-futurejair-bolsonaro-says-he-and-xi-jinping.

Dynamic, B. (2019). China's power in Africa: Rhetoric and reality. In J. Golley, L. Jaivin, P. Farrelly, \& S. Strange (Eds.), Power (pp. 186-200). ANU Press. Retrieved October 12, 2020, from http://www.jstor. org/stable/j.ctvfrxqkv.22.

Economy, E. (2018, June 29). The great firewall of China: Xi Jinping's internet shutdown. The Guardian. https:// www.theguardian.com/news/2018/jun/29/the-greatfirewall-of-china-xi-jinpings-internet-shutdown.

Fengyang. (2020, November 7). China's "dualcirculation" strategy means relying less on foreigners. The Economist. https://www.economist.com/ china/2020/11/07/chinas-dual-circulation-strategymeans-relying-less-on-foreigners.

Fitzgerald, J. (2019). Mind your tongue: Language, public diplomacy and community cohesion in contemporary Australia-China relations. Australian Strategic Policy Institute. doi:10.2307/resrep23070.5.

Green, M. (2019, April 25). China's debt diplomacy. Foreign Policy. https://foreignpolicy.com/2019/04/25/ chinas-debt-diplomacy/.

Greenpeace USA. (n.d.). 10 years ago the Amazon was being bulldozed for soy - then everything changed. https://www.greenpeace.org/usa/victories/amazonrainforest-deforestation-soy-moratorium-success/.

Halperin, S. (2020). Neocolonialism. In Encyclopædia Britannica. https://www.britannica.com/topic/neocolonialism.

Hernández, J.C., \& Chien, A.C. (2020, November 24). After Trump, Biden faces pressure to stand up to China by embracing Taiwan. The New York Times. https://www.nytimes.com/2020/11/24/world/asia/ taiwan-china-trump-biden.html.

Horn, S., Reinhart, C.M., \& Trebesch, C. (2020, February 26). How much money does the world owe China? https://hbr.org/2020/02/how-much-money-does-theworld-owe-china. 
Hsu, C. (2014). China's influence on Taiwan's media. Asian Survey, 54(3), 515-539. doi:10.1525/as.2014.54.3.515.

Kenton, W. (2020, September 8). Horizontal integration. Investopedia. https://www.investopedia.com/terms/h/ horizontalintegration.asp.

Kleven, A. (2019, May 9). Belt and Road: colonialism with Chinese characteristics. The Interpreter. https:// www.lowyinstitute.org/the-interpreter/belt-and-roadcolonialism-chinese-characteristics.

Lapper, R. (2019, April 23). Bolsonaro took aim at China. Then reality struck. Americas Quarterly. https://www. americasquarterly.org/article/bolsonaro-took-aim-atchina-then-reality-struck/.

Levitt, S. (2020, July 29). The simple economics of saving the Amazon rain forest (no. 428) [Audio podcast episode]. In Freakonomics. https://freakonomics. com/podcast/amazon-rain-forest/.

Li, A. (2017). CEFC news analysis: China facing the Trump presidency opportunities for global power projection? China Perspectives, 2(110), 69-73. Retrieved October 14, 2020, from http://www.jstor. org/stable/26380507.

Schroeder, R. (2018). Media systems, digital media and politics. In R. Schroeder (Ed.), Social theory after the internet: Media, technology, and globalization ( $\mathrm{pp}$. 28-59). UCL Press. doi:10.2307/j.ctt20krxdr.5.

Shah, R. (2020, April 24). A western delusion: Narratives surrounding neocolonialism in Africa. Oxford Political Review. https://oxfordpoliticalreview.com/ amp/2020/04/23/a-western-delusion-narrativessurrounding-neocolonialism-in-africa/.

Strauss, J. (2012). Framing and claiming: Contemporary globalization and "going out" in China's rhetoric towards Latin America. The China Quarterly, (209), 134-156. Retrieved October 12, 2020, from http:// www.jstor.org/stable/41447825.

Tham, E., \& Miller, M. (2016, April 22). Exclusive: Beijing auditions foreign public relations firms to polish China brand. Reuters. https://www.reuters. com/article/us-china-pr-exclusive/exclusive-beijingauditions-foreign-public-relations-firms-to-polishchina-brand-idUSKCN0XJ007.

Van Mead, N. (2018, July 31). China in Africa: win-win development, or a new colonialism? The Guardian. https://www.theguardian.com/cities/2018/jul/31/ china-in-africa-win-win-development-or-a-newcolonialism.

Westcott, B. (2018, March 11). Socialism with Chinese characteristics? Beijing's propaganda explained. CNN. https://www.cnn.com/2018/03/10/asia/china-npccommunist-party-phrases-intl/index.html. 